\title{
DIUŠENO (DUCHENNE) RAUMENŲ DISTROFIJA: KLINIKINIAI POŽYMIAI, DIAGNOSTIKA, GYDYMAS
}

\author{
Giedrius Šèmys \\ Vilniaus universiteto Medicinos fakultetas
}

Raktažodžiai: Duchenne raumenų distrofija, distrofinas, diagnostika, klinikiniai požymiai, gydymas, prednizolonas.

Santrauka

Duchenne raumenų distrofija (DRD) - paveldima neuroraumeninè liga, sukelta baltymo distrofino išraišką reguliuojančio DMD geno mutacijų, paveldimų su X chromosoma susijusiu recesyviniu būdu. Ligai būdingas greitai progresuojantis raumenų silpnejimas ir raumeninès masès praradimas dèl raumeninių skaidulų degeneracijos. Liga ịtariama pastebejjus vẻluojančią berniuko motorinę raidą. Nustačius padidejjusią kraujo serumo kreatinkinazès koncentraciją, atliekami genetiniai molekuliniai tyrimai, skirti DMD geno mutacijoms nustatyti. DRD gydymas yra palaikomasis, jo tikslas yra kuo ilgiau išsaugoti raumenų funkciją ir pagerinti gyvenimo kokybę; pagrindinis farmakologinis DRD gydymo būdas yra gliukokortikoidų terapija. Tyrimo tikslas - įvertinti ir išanalizuoti mokslinèje literatūroje pateikiamus duomenis apie Duchenne raumenų distrofiją ir aptarti ligos klinikines išraiškas, diagnostikos bei gydymo metodus.

\section{Ivadas}

Duchenne raumenų distrofija (DRD) - tai dažniausiai paveldima neurodegeneracinè raumenų distrofija, pasireiškianti greitai progresuojančiu raumenų silpnèjimu ir raumeninès masès praradimu dẻl skersaruožių, lygiưjų, miokardo raumenų degeneracijos. Liga paveldima su X chromosoma susijusiu recesyviniu būdu, todèl pasireiškia beveik tik berniukams. Ligos dažnis yra apie 1 atvejis iš 3500 gimusių berniukų, trečdalis atvejų kyla dèl naujų mutacijų [1]. Simptomai pasireiškia dèl mutacijų DMD gene, kuris koduoja baltymo distrofino išraišką žmogaus organizme. Dèl mutacijų distrofino gamyba sutrinka ir laikui bègant jo nepakanka užtikrinti normalią raumenų ląstelių funkciją [2]. Ši liga nepagydoma, jai progresuojant sparčiai prasteja paciento motorinè funkcija, pažeidžiama širdis, sutrinka kvejpavimo raumenų darbas; pacientai dažniausiai miršta 25-35 metų amžiaus [3].
Darbo tikslas- išanalizuoti bei aptarti ịrodymais pagrịstą informaciją apie Duchenne raumenų distrofijos klinikines išraiškas, diagnostiką bei gydymą.

\section{Tyrimo medžiaga ir metodai}

Taikyta sisteminè mokslinès literatūros bei dokumentu apžvalga ir analizè. Duomenų buvo ieškoma PubMed, Google Scholar, UpToDate bei Cochrane Libray duomenų bazėse. Visateksčiai straipsniai atrinkti, jei jų pavadinimas, santrauka ar reikšminiai žodžiai nurodè, kad tyrimas tinkamas šiai apžvalgai. Naudoti raktažodžiai: Duchenne muscular dystrophy, dystrophin, diagnosis, clinical features, treatment, prednisolone.

\section{Tyrimo rezultatai}

Klinikiniai požymiai. DRD būdingas progresuojantis raumenų silpnumas, ligos pradžioje paveikiantis kojų ir dubens raumenis. Iprastai DRD kliniškai pasireiškia tarp trečiujų ir penktujjų gyvenimo metų, retais atvejais simptomai gali išryškèti ir vèliau [3]. Raumenų silpnumas paprastai progresuoja tipiška eiga. Iš pradžių pažeidžiamos proksimalinių raumenų grupès, vèliau - distalinių; kojų raumenys pažeidžiami anksčiau nei rankų, dažniausiai stebima blauzdų raumenų pseudohipertrofija. Dèl progresuojančio kojų raumenų silpnumo DRD sergančiam berniukui sunku bėgioti, šokinèti ar lipti laiptais. Būdingas Gowers ženklas: sėdintis ant grindų pacientas stojasi, remdamasis rankomis. Ligai būdingas greitas progresavimas, dauguma pacientų iki 12 metų prikaustomi prie vežimèlio [2]. Ligai progresuojant, pažeidžiami kvėpavimo raumenys, vystosi dilatacinè kardiomiopatija, nugaros raumenų silpnumas sukelia skoliozę.

Diagnostika. DRD ịtarti reikia, kai: 1) kūdikiui ar ankstyvojo amžiaus berniukui nustatoma sutrikusi motorine raida, esant teigiamai šeiminei DRD anamnezei; 2) berniukas iki 16-18 mèn. nepradeda vaikščioti arba pastebimas Gowers ženklas, blauzdų pseudohipertrofija ar eisena pasistiebus ant 
kojų pirštų; 3) kraujo serume aptinkama padidejusi transaminazių koncentracija [4].

Itariant DRD, reikia išmatuoti paciento kraujo serumo kreatinkinazès (KK) koncentraciją. Aptikus padidejjusią KK koncentraciją, pacientas turi būti konsultuojamas neuroraumeninių ligų specialisto. DRD diagnozè mažai tikètina, jei išmatuota KK koncentracija yra normali. Tokiu atveju reikia svarstyti alternatyvias diagnozes [4].

Pagrindinis DRD diagnostikos metodas yra genetiniai molekuliniai tyrimai. Diagnozè patvirtinama nustačius ligą sukeliančią DMD geno mutaciją. Rekomenduojama genetinị tyrimą pradèti nuo didelių delecijų (duplikacijų) paieškos, kadangi šios DMD geno mutacijos formos yra dažniausios ir sukelia 70-80 proc. DRD atvejų. Jų neradus, rekomenduojama pereiti prie naujosios kartos egzomo arba genomo sekvenavimo, leidžiančio aptikti taškines mutacijas, sukeliančias 20-30 proc. ligos atvejų [5]. Anksčiau diagnozuojant DRD, didelę svarbą turèjo keturgalvio šlaunies raumens biopsija ir bioptato histopatologinis tyrimas, tačiau dabar šis metodas taikomas retai.

Gydymas. DRD yra nepagydoma liga, gydymas palaikomasis ir skirtas sustiprinti raumenis, ilgiau išsaugoti gyvenimo kokybę bei gebejjimą vaikščioti. Gliukortikoidai yra pagrindinis farmakologinis DRD gydymo būdas. Rekomenduojama skirti geriamaji prednizoloną $0,75 \mathrm{mg} / \mathrm{mg}$ kasdien. Klinikinių tyrimų duomenimis, prednizolonas pagerina motorines funkcijas, jègą, plaučių funkciją, mažina skoliozès riziką, pailgina gebejjimą savarankiškai vaikščioti [6-8].

Svarbu taikyti daugiadisciplinini bei reabilitacini gydymą, kadangi sergantiesiems DRD dažnos širdies, plaučių, ortopedinès, mitybos ir augimo problemos ar ịvairūs metaboliniai sutrikimai [3].

Šiuo metu kai kuriose šalyse jau taikoma genetinè terapija, naudojant ligos eigą modifikuojančius vaistus, tačiau kol kas dar trūksta klinikinių tyrimų duomenų, irodančių šio gydymo metodo efektyvumą.

\section{Išvados}

1. DRD būdingas progresuojantis raumenų silpnumas, pirmiausiai paliečiantis proksimalinius kojų raumenis, vẻliau paveikiantis ir kitas raumenų grupes.

2. DRD reikia įtarti pastebejjus sulètejjusią kūdikio ar ankstyvojo amžiaus berniuko motorinę raidą. Diagnozei patvirtinti atliekami genetiniai molekuliniai tyrimai DRD geno mutacijoms nustatyti.

3. DRD pagydyti šiuo metu neịmanoma. Taikomas palaikomasis gydymas gliukokortikoidais, kurio tikslas - sulètinti raumeninių skaidulų degeneraciją ir pagerinti paciento gyvenimo kokybę.

\section{Literatūra}

1. Centers for Disease Control and Prevention. Prevalence of Duchenne/Becker muscular dystrophy among males aged 5-24 years - four states, 2007. CDC 2009 ;58(40):1119-22.

2. Arora H. Duchenne muscular dystrophy: still an incurable disease. Neurol India 2019;67(3):717-723.

3. Osorio AN, Cantillo JM, Salas AC, Garrido MM, Padilla JJV. Consensus on the diagnosis, treatment and follow-up of patients with Duchenne muscular dystrophy. Neurol Engl Ed 2019;34(7):469-81.

https://doi.org/10.1016/j.nrleng.2018.01.001

4. Birnkrant DJ, Bushby K, Bann CM, Apkon SD, Blackwell A, Brumbaugh D, et al. Diagnosis and management of Duchenne muscular dystrophy, part 1: diagnosis, and neuromuscular, rehabilitation, endocrine, and gastrointestinal and nutritional management. Lancet Neurol 2018;17(3):251-67. https://doi.org/10.1016/S1474-4422(18)30024-3

5. Fox H, Millington L, Mahabeer I, Ruiten H. Duchenne muscular dystrophy. BMJ $2020 ; 368: 17012$.

https://doi.org/10.1136/bmj.17012

6. Matthews E, Brassington R, Kuntzer T, Jichi F, Manzur AY. Corticosteroids for the treatment of Duchenne muscular dystrophy. Cochrane Database Syst Rev 2016;(5):CD003725. https://doi.org/10.1002/14651858.CD003725.pub4

7. Gloss D, Moxley RT, Ashwal S, Oskoui M. Practice guideline update summary: corticosteroid treatment of Duchenne muscular dystrophy: report of the guideline development subcommittee of the American Academy of Neurology. Neurology 2016;86(5):465-72.

https://doi.org/10.1212/WNL.0000000000002337

8. Wein N, Alfano L, Flanigan KM. Genetics and emerging treatments for Duchenne and Becker muscular dystrophy. Pediatr Clin North Am 2015;62(3):723-42.

https://doi.org/10.1016/j.pcl.2015.03.008

\section{DUCHENNE MUSCULAR DYSTROPHY: CLINICAL FEATURES, DIAGNOSIS, TREATMENT G. Šèmys}

Keywords: Duchenne muscular dystrophy, dystrophin, diagnosis, clinical features, treatment, prednisolone.

Summary

Duchenne muscular dystrophy (DMD) is a genetic neuromuscular disease caused by mutations in the DMD gene, which encodes the protein dystrophin. It is inherited in an X-linked recessive pattern. DMD is associated with progressive muscle weakness and loss of muscle mass due to muscle fiber degeneration. DMD should be suspected when a boy fails to meet or experiences delayed motor development milestones. Elevated blood serum creatine kinase levels further raise suspicion for DMD and the diagnosis is confirmed by molecular genetic testing for mutations of the DMD gene. Treatment strategies for DMD are supportive and focus on preserving muscle function and improving quality of life; pharmacolo- 


\section{4}

gic treatment options are mainly limited to glucocorticoid therapy. The aim of this study is to evaluate and analyze the data presented in the scientific literature on DMD and to discuss the clinical features, diagnostic and treatment methods for DMD.

Conclusions: 1) DMD is associated with progressive muscle weakness that initially manifests in the proximal leg muscles and eventually affects other muscle groups; 2) DMD should be suspected when a boy experiences delayed motor development. The diagnosis is confirmed by molecular genetic testing for mutations of the DMD gene; 3) DMD is currently an incurable disease. The primary method of treatment is currently supportive glucocorticoid treatment focused on slowing down muscle degeneration and improving quality of life.

Correspondence to: giedrius.semys@gmail.com

Gauta 2021-04-21 